\title{
ANCHONUS DURYI \\ IN SOUTHEASTERN POLYNESIA (COLEOPTERA: CURCULIONIDAE: HYLOBIINAE: ANCHONINI) $)^{1,2,3}$
}

\author{
By Elwood C. Zimmerman \\ Bishop Museum, Honolulu
}

It was with much surprise that I found a species of the American genus Anchonus Schoenherr, 1825, when collecting in southeastern Polynesia 30 years ago during the course of Bishop Museum's Mangarevan Expedition. I learned later that A. M. Adamson had found the species on Tahiti a few years before my visit there, and, more recently, N. L. H. Krauss found the weevil on Raiatea. I had intended to report upon the discovery soon after the return of the Mangarevan Expedition, but the pressure of other work delayed this note.

I am grateful to Prof. F. M. Carpenter, Harvard University, who most kindly prepared the photographs reproduced here.

Anchonus is a genus of more than IOO species and is spread widely over parts of Mexico, Central America, northern South America, the West Indies and extending to such outlying areas as the Cocos and Galapagos Islands and to Florida in the United States. The greatest numbers of species are in the West Indies and Central America. The weevils are flightless ground-dwellers, and they appear most often to be found beneath decaying wood or other vegetation on the ground.

I have identified the species found in southeastern Polynesia as Anchonus duryi Blatchley, heretofore recorded only from Florida in the United States. I suspect that the species of Anchonus recorded from Florida are introductions to that area and are possibly natives of the West Indies.

In Florida, this weevil has been found under masses of sea weed and driftwood on beaches. Such a habit may make possible its wide dispersal by man. I presume that the weevil was transported to southeastern Polynesia after it had concealed itself in cargo that may have been stored on the beach before being loaded aboard ship. It may have been carried to Tahiti by sailing ship many years ago.

\footnotetext{
${ }^{1}$ A combined Pacific Entomological Survey and Mangarevan Expedition report.

${ }^{2}$ Rhynchophora of Southeastern Polynesia, part 12.

${ }^{3}$ This is the fifth of a series of reports resulting from the project "Pacific Island Weevil Studies" made possible by National Science Foundation research grant G-18933. Manuscript received by the editor May 1, 1964.
} 


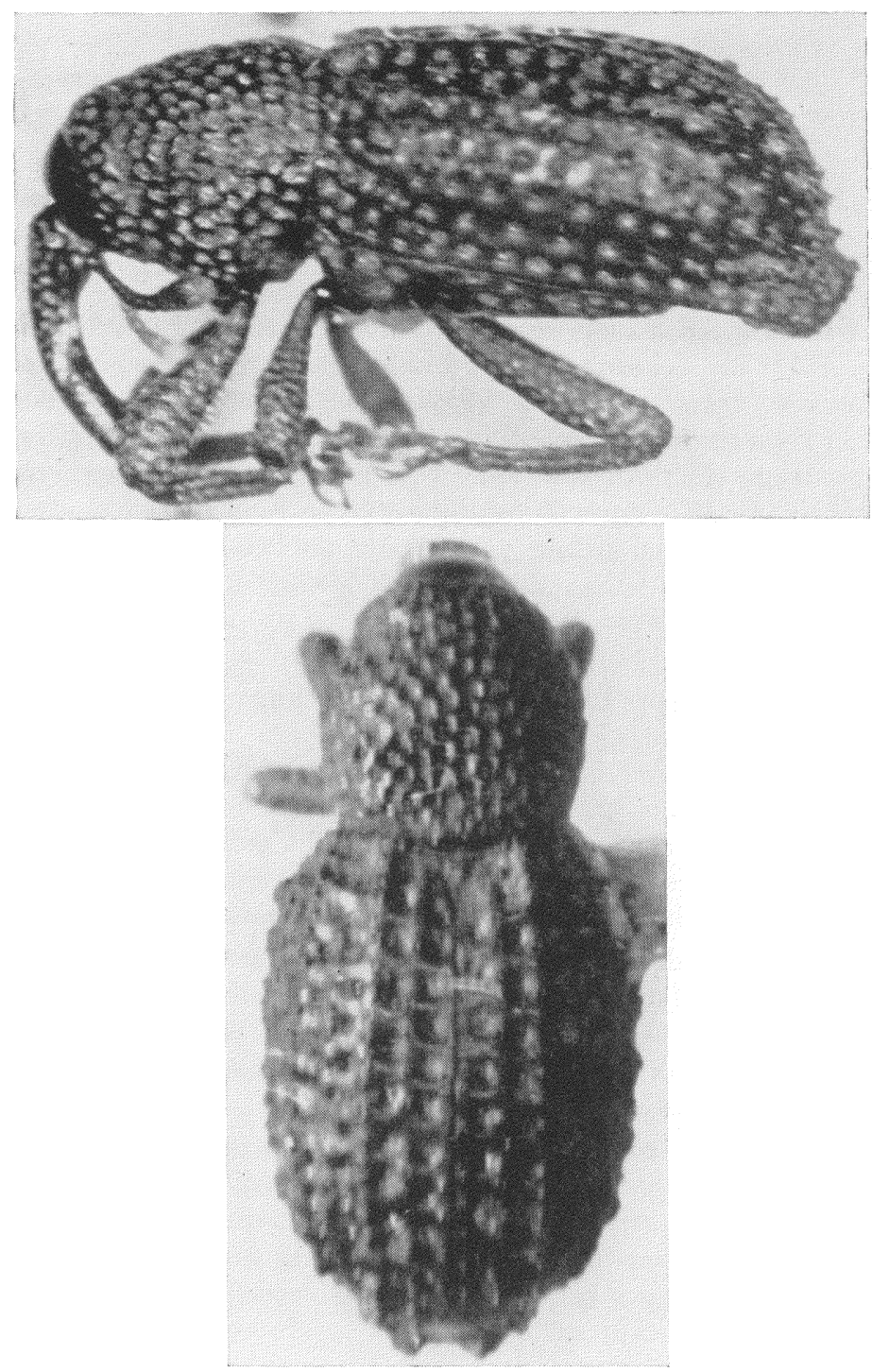

Explanation of Plate 8

Lateral and dorsal views of a female Anchonus duryi Blatchley from Raiatea, Society Islands. Length: $4.5 \mathrm{~mm}$., excluding head. (Photographs by Prof. F. M. Carpenter.) 


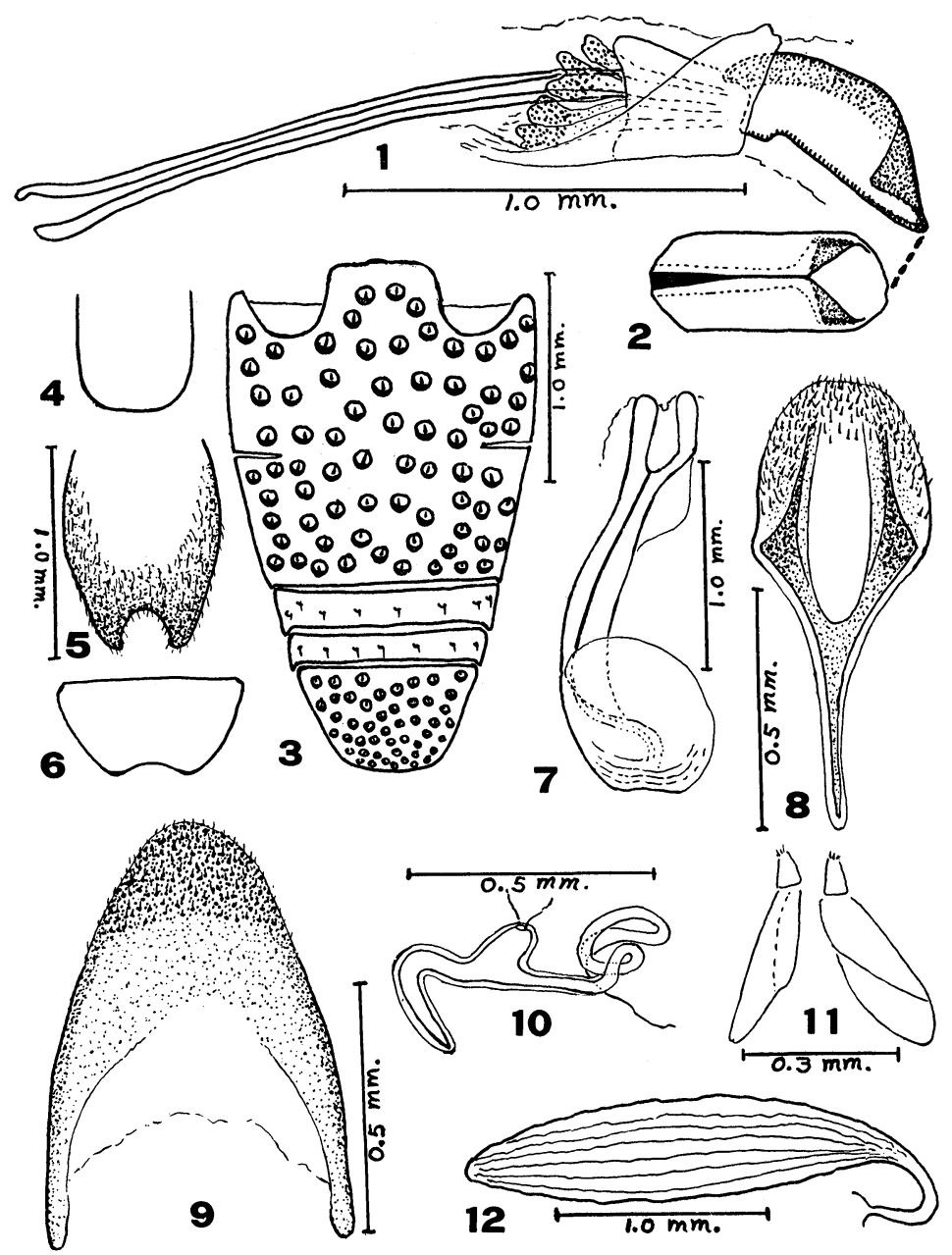

Figures 1-12: Anatomical details of Anchonus duryi Blatchley. 1, lateral view of aedeagus with phallobase ("tegumen") in situ (note lack of welldeveloped apodemes of phallobase); 2 , dorsal view of apical part of aedeagus drawn to same scale as $1 ; 3$, ventral view of abdomen of female; 4 , outline of pygidium of male; 5, pygidium of female; 6 , outline of ventrite five of male (compare shape of caudal margin with that of female); 7, urosternite ("spiculum gastrale") of male; 8 , urosternite of female; 9, eighth tergite of female; 10 , spermatheca (the convolutions vary) ; 11 , lobes of ovipositor; 12, the single ovary (this is sclerotized and is unusual because it persists after digestion in $\mathrm{KOH}$ ). The male specimen used for these drawings is from Tahiti; the female came from Florida, U. S. A. 
This is one of a very few American Curculionidae that have become established on mid-Pacific islands.

$$
\begin{aligned}
& \text { Anchonus duryi Blatchley } \\
& \text { Figures I-I } 2 \text { and Plate } 8
\end{aligned}
$$

Anchonus duryi Blatchley, 1916, Rhynchophora or Weevils of North Eastern America, p. 521, fig. 114 (poor).

Distribution : Florida, U.S. A. (type locality), introduced to the Society and Gambier Islands in southeastern Polynesia. The following data from 26 specimens are new:

Society Islands. Tahiti: I 5 specimens from Fautaua Valley, September 6, 1928, I I of these I mile from the sea and at about 50 feet elevation and 4 at 2 miles from the sea at about 75 feet elevation (A. M. Adamson); I found beneath a $\log$ at Tiupi Bay, Papiari, March 21, I934 (Zimmerman) ; 3 from the same place, April I2, I934 (Zimmerman). Moorea: I from Faatoai Valley, about 200 feet elevation, September 23, I934 (Zimmerman) ; 3 from beneath leaves in Tepatu Valley, between about 300 and 500 feet elevation, September 27, 1934 (Zimmerman). Raiatea: I from mountains near Uturoa, March, I955 (N. L. H. Krauss).

Gambier Islands. Mangareva Island: I from between 100 and 500 feet elevation on the northeast slope of Mount Duff, May 23, I934 (Zimmerman); I from near the convent at about 300 feet elevation, May 24, I934 (Zimmerman). 

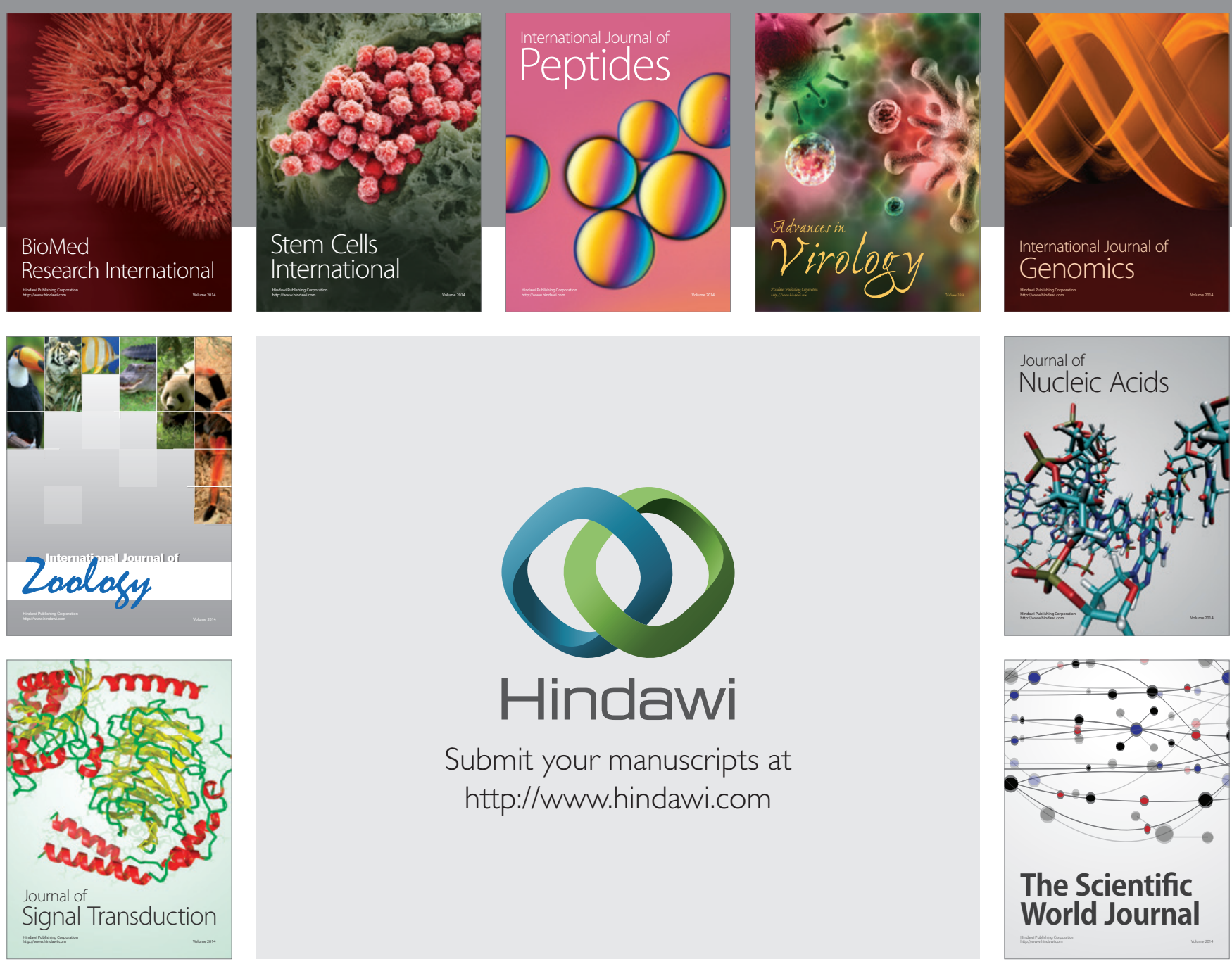

Submit your manuscripts at

http://www.hindawi.com
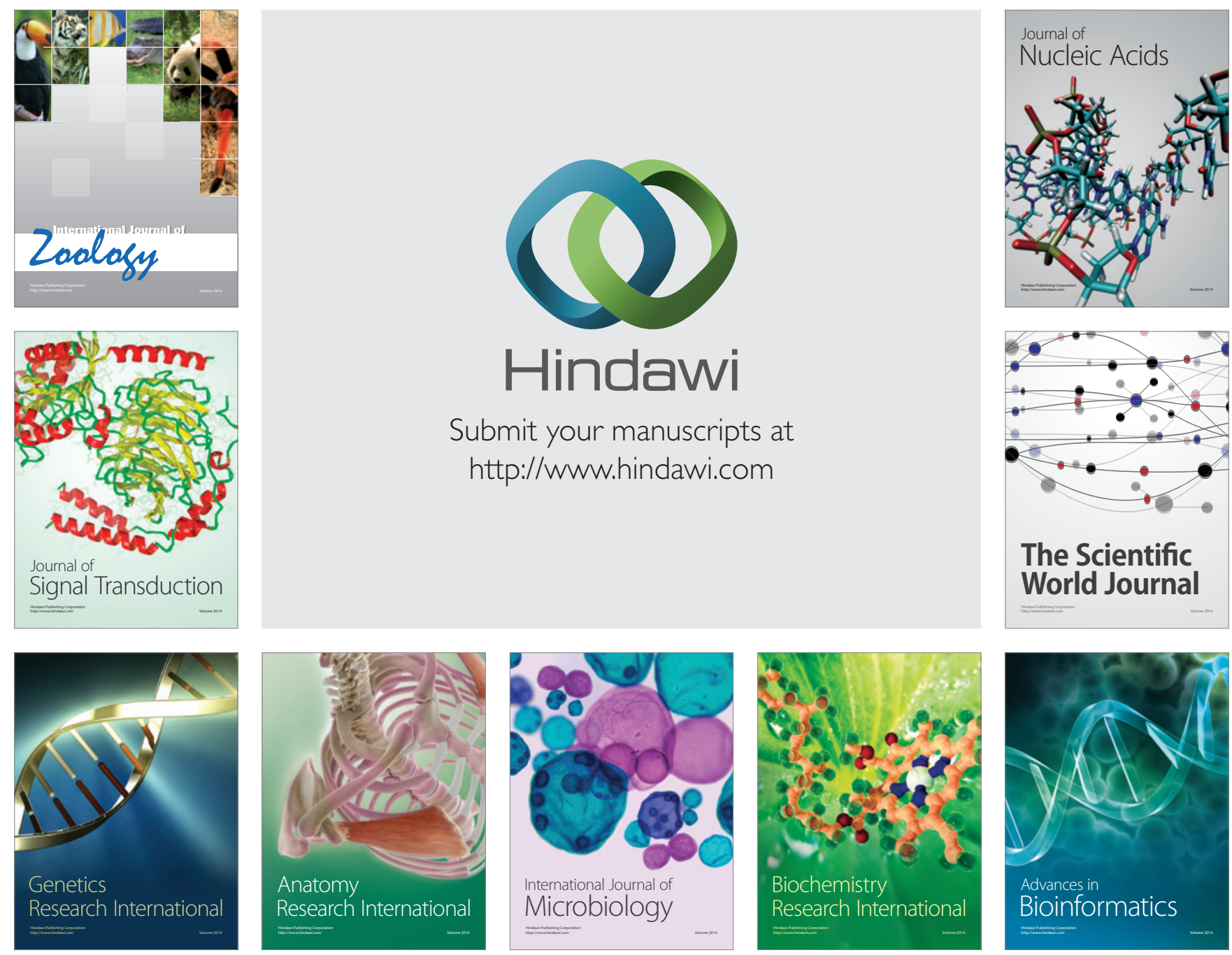

The Scientific World Journal
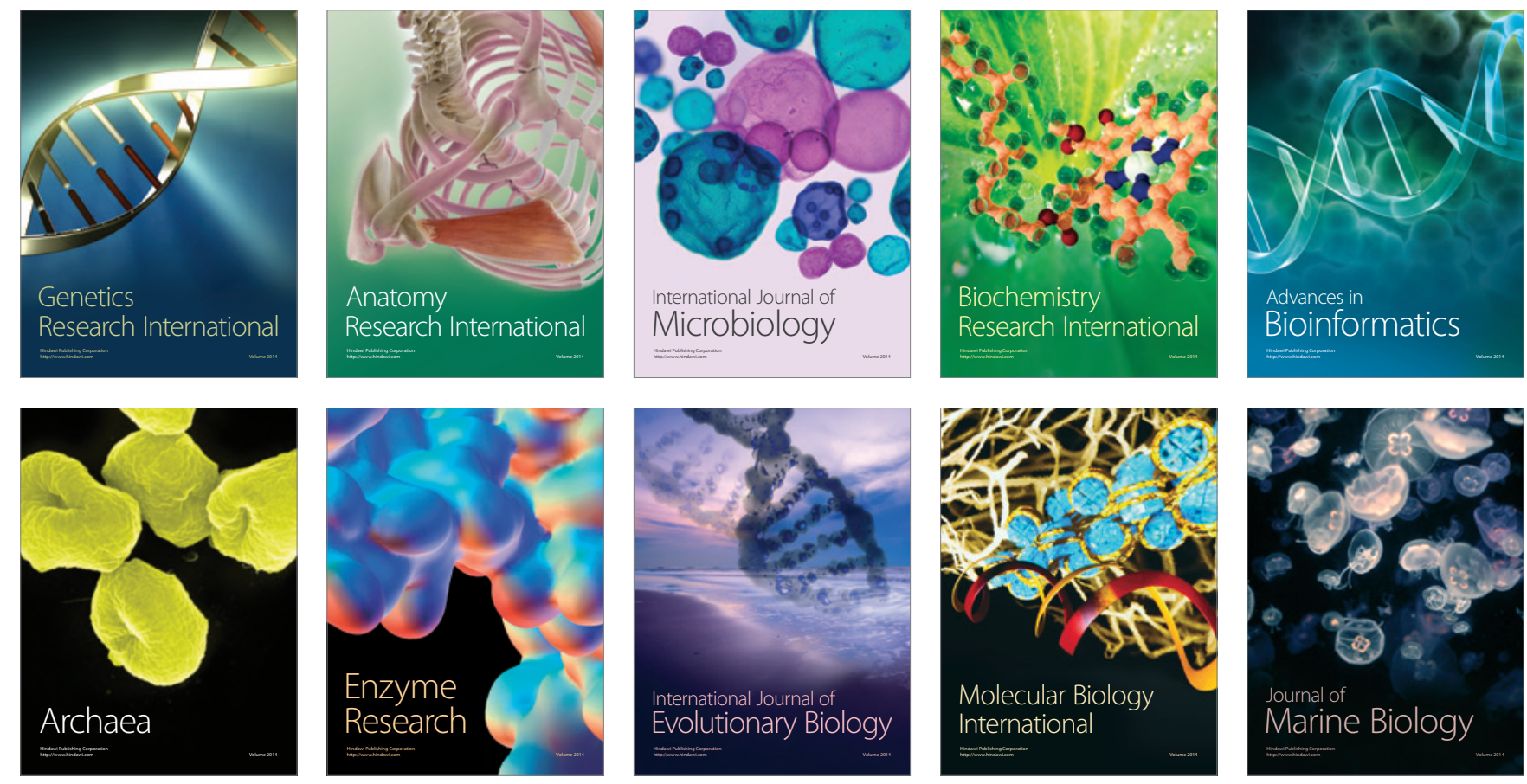